\title{
Processing Technologies of Lignocellulosic Biomass: Potentials and Constraints for Ruminant Feed Production
}

\section{(Teknologi Proses Biomasa Lignoselulosa: Potensi dan Kendala untuk Produksi Pakan Ruminansia)}

\author{
Simon Petrus Ginting \\ Loka Penelitian Kambing Potong Sungai Putih, Sumatera Utara \\ Kontributor utama: simonginting04@gmail.com
}

(Diterima 29 April 2021 - Direvisi 20 Mei 2021 - Disetujui 10 Juni 2021)

\begin{abstract}
Lignocellulosic biomass (LCB) such as crop residues and agro-industrial wastes are renewable resources and available abundantly. It could play central role in sustainable feeding system of ruminant production. These materials are potential source of fiber to support optimum rumen function and energy supply. However, the LCB has important nutritional constraints that limit its utilization as feed for ruminants. This review is intended to discuss nutritional constraints of LCB as ruminant feed and the potentials and challenges of processes in upgrading the nutritional quality of LCB. The main polymer compounds in LCB are cellulose (30 to $60 \%$ ), hemicellulose (20 to $40 \%$ ) and lignin (15-25\%) and its inter linkages make the energy contained in the LCB is less extractable by the ruminant digestive system. Physical, chemical and biological processing technologies have been well known as alternative means to upgrade the nutritive values of LCB. Recently, novel processing technologies of LCB such as ionic liquid, organosolv, sonication, and new screened rot white fungi (Ceriporiopsis subvermispora) and some older technologies using alkaline and acids have been studied and developed particularly for the purpose of biofuel production in the bio refinery industry. Processing technologies have different properties in degrading the lignin, degrading and solubilizing the cellulose and hemicellulose that all relate to the nutritive quality of LCB. Advantages of processed LCB in ruminant animals were indicated by increase in diet digestibility, intake, rumen fermentation and gain. It is concluded that numerous processing technologies are available to upgrade the nutritional quality of LCB, but there are obstacles to use some of these techniques for wide application in ruminant production system.
\end{abstract}

Key words: Lignocellulosic biomass, processing technology, feed, ruminants

\begin{abstract}
ABSTRAK
Biomasa lignoselulosa seperti hasil sisa tanaman dan industri agro merupakan sumberdaya terbarukan dan tersedia dalam jumlah besar, sehingga dapat berperan penting dalam sistim pakan berkelanjutan untuk mendukung produksi ruminansia. Biomasa tersebut merupakan sumber serat potensial untuk menjamin rumen berfungsi secara optimal. Namun demikian, materi tersebut memiliki beberapa kendala nutrisi yang membatasi penggunaannya seperti tingkat kecernaan dan konsumsi yang rendah serta kandungan nutrien penting seperti nitrogen yang juga rendah. Senyawa polimer utama dalam biomasa lignoselulosa selulosa $(30-60 \%$, hemiselulosa $(20-40 \%)$ dan lignin (15-25\%). Ikatan kimiawi yang terbentuk antar unsur polimer tersebut mengakibatkan energi yang dikandung kurang dapat dimanfaatkan oleh sistim cerna ternak ruminansia. Teknologi proses secara fisik, kimiawi maupun biologis telah banyak dikembangkan sebagai upaya meningkatkan kualitas nutrisi biomasa lignoselulosa. Beberapa teknologi proses yang lebih dulu diteliti seperti larutan amonia cair dan amonia dengan tekanan tinggi dan hidrogen peroksida merupakan teknologi proses yang menjanjikan. Akhir-akhir ini, berbagai teknologi proses baru telah diteliti terutama bertujuan untuk memproduksi bahan bakar, seperti penggunaan ion cair, pelarut organik dan inorganik (organosolv), sonikasi, iradiasi gelombang mikro, sinar gama, tekanan hidrostatik, maupun penggunaan strain baru jamur putih (Ceriporiopsis subvermispora). Penggunaan teknologi proses biomasa dalam produksi pakan telah berhasil meningkatkan kecernaan dan konsumsi pakan, tingkat fermentasi rumen dan pertambahan bobot badan pada ternak ruminansia. Berbagai teknologi proses ini menghasilkan pengaruh yang bervariasi dalam mendegradasi lignin, mendegradasi dan melarutkan selulosa dan hemiselulosa yang semuanya terkait dengan kualitas nutrisi biomasa. Disimpulkan bahwa sejumlah teknologi proses yang tersedia dapat meningkatkan kualitas nutrisi biomasa lignoselulosa, namun terdapat pula berbagai kendala teknis maupun ekonomis dalam penerapannya secara luas di dalam sistim produksi ternak ruminansia.
\end{abstract}

Kata kunci: Biomasa lignoselulosa, teknologi proses, pakan, ruminansia 


\section{INTRODUCTION}

In ruminant feeding system crop residues are important feed resources in many regions in the world. Quantitatively, it is estimated that there are about 150 billion metric ton of lignocellulosic biomass (LCB) produced from the agricultural practices globally (Guerriero et al. 2016). In Indonesia, for example it is estimated that there are at least 300 million metric ton of biomass production annually of LCB from the plantation crops and its mill processing such as oil palm fronds, palm oil empty bunch, palm press fiber, oil palm trunks, cocoa pod husk and sugar cane (Widiawati et al. 2019). Meanwhile, there is approximately 82 million ton of rice straw produced in 2019 calculated based on rice/straw convertion ratio of 1/1.5 (Makarim et al. 2007) and rice production of 54.6 million ton (BPS 2020). LCB are renewable resources and can play central role in developing a sustainable feeding system for ruminant animal production by converting it into feeds to generate high quality food for human. Less utilization of arable land to produce feed for livestock can be expected by maximizing the utilization of LCB as ruminant feed (Van Zanten et al. 2019). It is estimated that globally $40 \%$ of the total cropland is used to produce feeds for livestock and about $30 \%$ of the global cropland is allocated to cereals intended for livestock feed that could be consumed directly as human food (Musacat et al. 2019). To mitigate the competition of food and feed for limited resources, ruminant should be directed to use more nonedible feedstuffs and renewable biomass as a significant component of its feeding system. This approach would also potentially reduce wastes to minimize environmental pollution. However, the cell wall of LCB become more lignified as the plant matures resulted in low digestibility and intake. Providing unprocessed LCB to ruminants causes low production rate mainly due to low available energy for metabolic activities. The processing of this LCB is an important step to make these materials become more digestible so that more energy could be extracted metabolically from it to support production. The current widely adopted processing of LCB as feed for ruminants is mainly the physical process such as chopping and shredding. These processes are relatively simple and requires less capital to operate. However, it did not provide changes in the chemical structure of the LCB cell wall components. This review will discuss nutritional constraints of LCB as ruminant feed and effects of several conventional and recent developed processesing technologies on LCB. The responses of ruminants on the processed LCB are presented and the potential of these processing technologies in the Indonesia ruminant production setting is discussed.

\section{NUTRITIONAL CONSTRAINTS OF LIGNOCELLULOSIC BIOMASS (LCB)}

Most of LCB mainly composed of heterogenous complex polymer of carbohydrates (cellulose and hemicellulose) and polymer of phenylpropanoid unit (lignin). In cereal crop residues such as rice straw, wheat straw, corn stover, corn cobs the lignin content ranges from 9 to $22 \%$, cellulose and hemicellulose contents range from 32 to $59 \%$ and from 24 to $35 \%$, respectively (Kumar \& Sharma 2017; Huang et al. 2016). Relatively high lignin content (21.6\%) was found in sugar cane bagasse with cellulose and hemicellulose contents of 42.9 and $27.6 \%$, respectively (de Morales Rocha et al. 2015). Biomass such as oil palm fronds, oil palm empty bunch, oil palm trunks and palm pressed fibre contained relatively high lignin ranging from 15 to $28 \%$ (Intasit et al. 2019; Rizal et al. 2018; Zakaria et al. 2014; Hashim et al. 2011; Hassim et al. 2012). In LCB the major part of these three components is cellulose, but although lignin comprises the least amount, it negatively affects the utilization of cellulose and hemicellulose as important energy sources for ruminant animal production. As ruminant feed, the LCB have only 4-6\% average crude protein and 1.5-2.6 Mcal ME/kg DM (Akram \& Firincioglu 2019 ) with potential intake at $1.0-1.2 \%$ of body weight. The caloric values of LCB materials from oil palm plantation and industry are limited to support ruminant production (Ginting et al. 2018). In several cereal straws, the digestibility is less than $50 \%$ (Mahesh \& Mohini 2013) and closely correlate to the contents and compositions of its major constituents. The LCB do not only differ greatly in the amount of lignin, cellulose and hemicellulose, but could also vary in the degree of polymerization, compositions of the building unit of the lignin and degree of crystallinity of the cellulose structure (Behera et al. 2014). Therefore, delignification of LCB is a critical process in optimizing the utilization of such material for animal feeds. Furthermore, purified lignin could be used as antioxidant feed additive in ruminants as shown in cattle by Wang et al. (2017) or for other valuable industrial products such as adhesives, surfactants and absorbents (Talaiekhozani \& Rezania 2020).

\section{PROCESSING TECHNOLOGIES OF LCB FOR RUMINANT FEED PRODUCTION}

Due to the limited nutritional capacity of LCB to support high ruminant productivity processing technologies are required to make the most of its huge quantitative potentials. Pretreated LCB will further mechanically processed by ruminants through chewing and ruminating activities. Processing technologies could act as important preparatory processes for 
maximal chewing and rumination and further extensive digestion in the rumen to extract the metabolic energy contained in the LCB to support ruminant production. Processing technologies are commonly classified into mechanical, physical, chemical, and biological treatment that alters the physical and chemical properties of the LCB. The main purpose is to break the linkages between lignin, cellulose and hemicellulose and to disrupt the crystallinity of the cellulose or increase the porosity of the cellulose and hemicellulose (Behera et al. 2014; Kucharska et al. 2018). All of these structural and chemical alterations will enhance the access of enzymes secreted by the rumen microorganisms and increase the cellulose and hemicellulose fermentability. It is important to note that ideally, any processing technologies should keep the cellulose and hemicellulose to be conserved as much as possible for ruminal fermentation to maximize the yield of volatile fatty acids and ATP for the synthesis of microbial protein in the rumen.

Various classical and the emerging technological processes of LCB are now available to fractionate, solubilize, hydrolyze and separate cellulose, hemicellulose, and lignin components. Recent technological processes have been researched and developed mainly in the bio-refinery production of biofuel (Aditiya et al. 2016; Kumar \& Sharma 2017; Panahi et al. 2020). Principally, all these processing technologies are compatible with the intention of LCB utilization for ruminant production.

\section{MECHANICAL AND PHYSICAL-BASED PROCESSES OF LCB}

Mechanical process aims to process LCB into smaller particle size to facilitate chewing and ruminating process that enhance the surface area of digesta particles and more accessible to the rumen microorganisms. Reduced particle size will also reduce sorting by the animals and enhance feed intake. Grinding of LCB could be performed using hammer or roller type of grinders. The hammer type-grinder crush the material by repeated blows of hammers. The roller type of grinder uses cylindrical roller in opposing pairs to crush the materials. This method usually resulted in very small $(0.2 \mathrm{~mm})$ particle size materials (Kumar \& Sharma 2017). As an animal feed the very small particle size LCB are lacking of physical characteristic crucial for optimum rumen function (Adesogan et al. 2019). Therefore, grinding and milling process would be most suitable for production of pellet feed although this process is expensive since it requires a lot of energy that limits its application for ruminant feed production.

Chopping is a mechanical process that yield coarser (>10 cm) particles (Kumar \& Sharma 2017).
The advantage of this mechanical process is that it only reduces the length of LCB particles and not its diameter so the effective fiber-properties of the chopped LCB is maintained. It may also increase the rate of passage through the rumen that subsequently increase the feed intake by animals, and still have physical properties required for optimal rumen fermentation, and less energy is required to perform the process (Adesogan et al. 2019). However, chopping could reduce the digestibility of the LCB due to the increased rate of passage of the chopped LCB along the gastrointestinal tract of the ruminants. Shredding is another mechanical process that not only reduce the length of LCB particle but also crush or tear the material and cause greater physical damages to LCB (Adesogan et al. 2019). Shredding process would increase the digestibility of the LCB by facilitating efficient chewing and ruminantion and further digestion in the rumen. It is suitable to pretreat the relatively hard LCB such as oil palm frond, oil palm trunk, oil palm empty bunch. The energy required for shredding increases with higher moisture content, larger initial particle size and smaller final particle size (Montgomery \& Bochman 2014). Chopping and shredding may aid ruminants to chew and ruminate feed particle more efficiently.

Steam explosion is one of the physical process that has been studied extensively for upgrading the LCB for ruminant feeds (Mokomele et al. 2018; Rusli et al. 2019; Wu et al. (2020). This method typically proceed by rapidly heating the LCB at relatively high temperatures $\left(160-260^{\circ} \mathrm{C}\right)$ and by high-pressure steam (0.7-4.8 $\mathrm{MPa})$ and terminated by explosive decompression (Kumar \& Sharma 2017). Hemicellulose is hydrolyzed and acid is generated during the process. Removal of hemicellulose is the disadvantage of this method intended for animal feed production. There are more recent physical processing technologies that have been studied including microwave irradiation, ultrasound, gamma ray, electron beam, pulse electric field, high hydrostatic pressure and high pressure homogenization. in the bio-refinery system (Kumar \& Sharma 2017; Kucharska et al. 2018). The mode of actions of these physical processings vary but it has common impact on disruption of the lignocellulosic matrix resulting that cellulose and hemicellulose are more readily exposed to hydrolytic enzymes. Sonication (ultrasound) process for example altering the morphology of the LCB by forming cavitation bubbles that ruptures cellulose and hemicellulose fraction by ultrasound waves (Karunanithy et al. 2011; Kucharska et al. 2018). Pulse electric field method disrupts the cell wall membrane by generating pores to increase the penetration of hydrolytic enzymes into the cell wall matrix (Kumar \& Sharma 2017). Currently, the cost effectiveness of these technologies is the most limiting factor for widely 
commercial application and it seems that information on the utilization of these emerging technology of LCB for of animal feed production is unavailable.

\section{RESPONSE OF RUMINANTS TO MECHANICALLY AND PHYSICALLY PROCESSED LCBS}

Combination of chopping with pressure on oil palm fronds fed to goats resulted in improvement in feed degradability and ruminal VFA concentration (Rusli et al. 2019). It was suggested that the beneficial effects of chopping process on LCBs was greater when they had low digestibility (Malik et al. 2015) and that nitrogen can be a limiting factor for optimum improvement effect of reducing particle size of LCB with very poor digestibility. Steam explosion method has been studied extensively in ruminants. In vitro study using rumen liquid from dairy cow on sugar cane bagasse pretreated by steam explosion showed increased DM digestibility by 54\% (Mokomele et al. 2018). Other study in dairy cow (Wang et al. 2020) showed that the NDF and ADF digestibility of corn stover pretreated by steam explosion increased by 26.1 and $27.1 \%$, respectively and methane production decreased by $9.5 \%$. Using steam explosion process on oil palm empty bunch increase metabolizable energy by $13.5 \%$ when fed to steer (Wu et al. 2020). In the same study, increased total ruminal VFA concentration by $17.3 \%$ was also detected when oil palm fronds were pretreated by steam explosion.

\section{CHEMICAL-BASED PROCESS OF LCBS}

Chemical treatments of LCBs have been explored extensively in attempting to upgrade their nutritive quality for ruminants using various chemicals as hydrolyzing agent such the alkaline, mineral acids, organic acid and oxidizing agents. Alkaline treatment is probably one of the most studied processes that have been studied in converting LCB into ruminant feeds. The alkaline processes employ various chemical agents such as sodium hydroxide, calcium hydroxide, potassium hydroxide, aqueous ammonia, and ammonium hydroxide (Agbor et al. 2011; Behera et al. 2014). The effects of alkaline process on the LCB main components is shown in Table 1. The effect of alkaline agents including swelling the LCB leading to increased specific area, degrading the side chain of ester and glycosides, degrading, dissolving, removing and altering the structure of lignin, reducing the crystallinity of the cellulose and solvate the hemicellulose. It is shown that alkaline agents are capable of removing lignin by 30 to $80 \%$, depending on the alkaline agents and substrates used. Although some hemicellulose was removed, most of the cellulose was retained by the alkaline treatments. Alkaline process is effective in swelling and increasing the internal surface area of cellulose, breaking the linkages between the lignin and the polysaccharide and solubilizing the lignin (Balan 2014).

The effect of acids and oxidative treatment on the main components of various type of LCB are presented in Table 2. It is shown that significant amount of lignin $(19-81 \%)$ could be removed by these chemical processes depending on the chemical agents and substrates used. Most of the cellulose are retained while hemicellulose is partially retained. Sulfuric acid $\left(\mathrm{H}_{2} \mathrm{SO}_{4}\right)$ has been a conventional acid treatment of LCB. Diluted sulfuric acid is preferred than the concentrated one since the former is less corrosive, generate less inhibitory products and environmentally friendly process (Behera et al. 2014). The specific surface area of oil palm fronds treated with diluted acid $\left(\mathrm{H}_{2} \mathrm{SO}_{4}\right)$ at $121^{\circ} \mathrm{C}$ for 30 minutes increased from 2.23 to $5.57 \mathrm{~m}^{2} / \mathrm{g}$ (Kristiani et al. (2013). The increase in specific surface area of the LCB materials is due to hydrolysis of the cellulose and hemicelluloluse and dissolving of the lignin by the acid. This change in the morphological surface is indicative of decreasing crystallinity of cellulose molecules. Organic acids produce less degradation products than mineral acids (Balan 2014). Organic acids such as oxalic acid (Lee et al. 2011) and malic acid have been carried out as alternative treatment to overcome the disadvantages of sulfuric acid (Kumar \& Sharma 2017). Most of acid treatment also hydrolyze hemicellulose, particularly the xylan. Combination of organic solvents in inorganic acids (Organosolv) is a process that is mainly used to extract lignin by disrupting the linkage between the lignin and the hemicelluloses. The common organic acids used include ethanol and methanol (Kumar \& Sharma 2017), oxalic and salicylic (Behera et al. 2014), while the common inorganic acids are chloric and sulfuric acids. The organosolv process usually proceed at high temperature $\left(150-200^{\circ} \mathrm{C}\right)$. Other recent chemical treatment is the ionic liquids such as imidazolium salt that could dissolve lignin by disrupting the hydrogen bonding of the lignocellulosic complexes (Kucharka et al. 2018). It is inexpensive process and can be conducted under low and mild temperature and selectively depolymerize the lignin. It is attractive for industrial scale because it is not volatile making it is environmentally friendly treatment (Kucharska et al. 2018), but to the author's knowledge this type of processing has not been studied for animal feed purposes.

Oxidative process uses oxidizing agents to degrade the lignin in LCB, but it also dissolves some hemicellulose and the amorphous cellulose, but not the crystalline cellulose (Kucharska et al. 2018). Hydrogen 
peroxide is the most commonly used oxidizing agent that generates hydroxyl radical to degrade the lignin into acids (Kumar \& Sharma 2017). This hydrolyzing agent is very mild and does not pollute the biomass (Kucharska et al. 2018). Oxidative process of corn stover using hydrogen peroxide resulting in lignin removal by $81.6 \%$, while $95 \%$ of glucan and $70 \%$ of xylan were retained (Saha \& Cotta 2014). Ozonolysis is a process that uses ozon as strong oxidizing agents that oxidize lignin into acids, but also degrade the hemicellulose and cause the swelling of biomass. Cellulose is not affected by ozonolysis due to its linear structure, but this process is expensive (Kucharska et al. 2018).

Table 1. Effects of alkaline-based process on the main polymer components of several LCBs potentially used as feed for ruminants

\begin{tabular}{|c|c|c|c|}
\hline Processing technology & Procedures & LCB & Results \\
\hline $\begin{array}{l}\text { Aqueous ammonia } \\
\text { soaking (AAS) }\end{array}$ & $\begin{array}{l}\text { Biomass is soaked in } 15 \% \\
\text { aqueous ammonia, biomass/ } \\
\text { ammonia ratio } 1 / 5 \text {, for } 12 \mathrm{~h} \text { at } \\
40 \text { to } 80^{\circ} \mathrm{C}\end{array}$ & Oil palm empty fruit bunch & $\begin{array}{l}\text { Removed lignin by } 36 \text { to } \\
43 \% 1\end{array}$ \\
\hline $\begin{array}{l}\text { Aqueous ammonia } \\
\text { soaking (AAS) }\end{array}$ & $\begin{array}{l}\text { Soaked in aqueous ammonia at } \\
\text { concentrations } 5 \text { to } 20 \% \text { at a } \\
\text { solid to liquid ratio of } 1: 10 \text {, } \\
120^{\circ} \mathrm{C} \text { for } 60 \mathrm{~min}\end{array}$ & Rice straw & $\begin{array}{l}\text { Removed lignin by } 55 \text { to } \\
69 \%^{2}\end{array}$ \\
\hline $\begin{array}{l}\text { Ammonia fiber explosion } \\
\text { (AFEX) }\end{array}$ & $\begin{array}{l}\text { Aqueous ammonia with ratio of } \\
(1 / 1-2) \text {; at } 60-90^{\circ} \mathrm{C} \text {, at pressure } \\
>3 \mathrm{MPa}, 15 \text { minutes }\end{array}$ & Corn stover & $30 \%$ lignin is removed ${ }^{3}$ \\
\hline Sodium hydroxide & $\begin{array}{l}4 \% \mathrm{NaOH} \text { at } 150^{\circ} \mathrm{C} \text {, for } 30 \\
\text { minutes, } 500 \mathrm{~g} \text { substrate } / 2.5 \mathrm{~L} \\
\text { solution }\end{array}$ & Oil palm empty fruit bunch & $\begin{array}{l}30 \% \text { lignin and } 28 \% \\
\text { hemicellulose were removed }\end{array}$ \\
\hline $\begin{array}{l}\text { Alkaline hydrogen } \\
\text { peroxide (AHP) }\end{array}$ & $\begin{array}{l}\text { Process in } 2 \% \mathrm{H} 2 \mathrm{O} 2 \text { solution } \\
(\mathrm{v} / \mathrm{v}), \mathrm{pH} 11.5,35^{\circ} \mathrm{C}, 24 \mathrm{~h}, 10 \% \text {, } \\
\mathrm{w} / \mathrm{v}\end{array}$ & Corn stover & $\begin{array}{l}81.6 \% \text { lignin was removed, } \\
95 \% \text { gulan and } 70 \% \text { Xylan } \\
\text { were retained }^{6}\end{array}$ \\
\hline Sodium hydroxyde & $\mathrm{NaOH} 1 \mathrm{~N}$, for 30 minutes & Sugar cane bagasse & $\begin{array}{l}\text { Lignin content decreased by } \\
59.1 \%^{5}\end{array}$ \\
\hline Lime processing & $5 \mathrm{~g}$ biomass $/ 2 \mathrm{~g} \mathrm{Ca}(\mathrm{OH}) 2$ & Corn cob & $34 \%$ lignins were removed ${ }^{7}$. \\
\hline
\end{tabular}

${ }^{1}$ Latif et al. (2018); ${ }^{2}$ Swain \& Krishnan (2015); ${ }^{3}$ Uppugundla et al. (2014); ${ }^{4}$ Barlianti et al.(2015); ${ }^{5}$ Saha \& Cotta (2014); ${ }^{6}$ Maryana et al.(2014); ${ }^{7}$ Mafa et al.(2020)

Table 2. Effects of acid-based process on the main polymer components of several LCBs potentially used as feed for ruminants

\begin{tabular}{|c|c|c|c|}
\hline $\begin{array}{l}\text { Processing } \\
\text { technology }\end{array}$ & Procedures & LCB & Results \\
\hline Ionic liquid & $\begin{array}{l}\text { Processing with (1-ethyl-3- methylimidazolium-diethyl } \\
\text { phosphate) and (1-ethyl-3-methylimidazolium acetate), } \\
\left(70-100^{\circ} \mathrm{C}\right) \text { for } 4 \mathrm{~h}\end{array}$ & Oil palm fronds & $\begin{array}{l}\text { Lignin content decreased by } 19.6- \\
68.8 \% 1\end{array}$ \\
\hline Orgnanosolv & $\begin{array}{l}\text { Substrate was mixed with citric acid with } 1: 16(\mathrm{w} / \mathrm{w}) \\
\text { ratio }\end{array}$ & Coffee pulp & $\begin{array}{l}\text { Lignin content decreased by } 19.6- \\
68.8 \%{ }^{2}\end{array}$ \\
\hline Organic acid & $\begin{array}{l}\text { Solution of } 30 \mathrm{~g} / \mathrm{l} \text { of oxalic acid in a } 500-1 \text { reactor for } 20 \\
\text { min at room temperature. The solid:liquid ratio during } \\
\text { impregnation was } 1: 6\end{array}$ & Corn cob & $\begin{array}{l}13.5 \% \text { lignin was removed, } \\
\text { glucan was retain, and } 75.7 \% \\
\text { xylan was removed }\end{array}$ \\
\hline Mineral acid & $\begin{array}{l}\mathrm{H}_{2} \mathrm{SO}_{4}(0.5-1.5 \%) \text {, for } 120 \text { minutes, at } 25^{\circ} \mathrm{C} ; 6 \% \\
\text { biomass /solvent ratio }\end{array}$ & Cocoa pod & Lignin content decreased by $46 \%$ \\
\hline Mineral acid & $1 \% \mathrm{H}_{2} \mathrm{SO}_{4}$; at $25^{\circ} \mathrm{C}$, for $18-24$ hours & Wheat straw & $\begin{array}{l}50 \% \text { delignification, partial } \\
\text { dissolution of hemicellulose }{ }^{5}\end{array}$ \\
\hline
\end{tabular}

${ }^{1}$ Tan et al. (2011); ${ }^{2}$ Lini et al. (2018); ${ }^{3}$ Lee et al. (2011); ${ }^{4}$ Nazir et al. (2016); ${ }^{5}$ Kucharska et al. (2018) 


\section{RESPONSES OF RUMINANTS TO CHEMICALLY-BASED PROCESSED LCB}

Recents in vitro and in vivo studies have evaluated the effect of chemical process of LCB in ruminant. Carperson et al. (2018) treated corn stover with calcium hydroxide to replace partially (15-30\%) forages in diet of dairy cow and found no negative effects in milk production and compositions. Using lime $(\mathrm{CaO})$ as alkaline treatment on wheat straw and fed to steers at the rate of 25\% DM in diet, Shreck et al. (2015) found increased average daily gain by $5.6 \%$ and did not affect feed intake so that feed efficiency was improved by $6.2 \%$. Ahmadi et al. (2016) combined sodium hydroxide and calcium hydroxide as alkaline processing treatment on sugar cane bagasse and found that the in situ degradability of NDF at 24 and $48 \mathrm{~h}$ incubations were increased by 1.9 and 1.58 fold, respectively. Urea as alkaline processing treatment has additional advantage that it also supply nitrogen to the LCB that could be converted by the microorganisms in the rumen into their protein cell. Recent study by Laconi \& Jayanegara (2015) indicated that using ureatreated cocoa pod husk at $35 \%$ of DM diet of steer resulted in increased OM intake, OM digestibility and body weight gain by $73.3,7.2$ and $105.2 \%$, respectively. It is suspected that the combination effects of increase in feed intake and digestibility would have provide significantly more metabolizable energy to support the growth. Ammonia Fiber Explosion (AFEX) is one of alkaline processing treatments that have potential for application in ruminant feeding system based on LCB. In this process, liquid anhydrous ammonia is pressurized to the LCB.

The process operate at mild temperature (60$\left.100^{\circ} \mathrm{C}\right)$ at high pressure (250-300 psi) for 5 to 30 minutes (Latief et al. 2018). Significant increase in in vitro true digestibility (69\%) of sugar cane bagasse treated by AFEX was reported by (Mokomele et al. 2018). Mor et al. (2018) studied the effects of inclusion of AFEX treated wheat straw in lactating cows and buffaloes. In lactating cow, they indicated that including AFEX-treated wheat straw in diet DM at $48.5 \%$ resulted in increased intake by $42 \%$ and milk energy content by $18 \%$, while in buffaloes with similar rate of inclusion no effects on intake and milk production and decrease in BW loss by $42 \%$ were recorded. In goat, when concentrate was replaced by AFEX- treated wheat straw with the inclusion rate of 50\% of diet (DM), the average daily gain (ADG) was attained at $55.6 \mathrm{~g}$ with feed conversion ratio (FCR) of 9.9 and no effects were detected on rumen fermentation and blood metabolites (Mor et al. 2019). Falls et al. (2017) combine of oxidative lime process with pressure on corn stover and found considerable improvement $(60 \%)$ in the in vitro neutral detergent fiber (NDF) digestibility $(49.3 \%$ in untreteated vs. $79 \%$ in treated stover) and $40 \%$ improvement in total digestible nutrient (TDN) $(51.0 \%$ in untreated vs $72.6 \%$ in treated corn stover).

\section{BIOLOGICAL-BASED PROCESS OF LCB}

The purpose of biological processing treatment on LCB is to increase its DM digestibility when offered to ruminants. The increase in LCB DM digestibility is related to the cleavage of linkages between lignin and cellulose and hemicellulose catalyzed by lignase secreted by microorganisms. Microorganisms like white and brown-rot fungi have been used to pretreat LCB since they produce effective lignin degrading enzymes such as peroxidases and laccases (Balan 2014). Degradation of main components of LCB varied considerably due to type LCB, species of microorganisms and incubation time (Table 3). Phanerochaete chrysosporium is capable of degrading lignin but it also extensively degrades cellulose in wheat straw, oil palm press fiber and maize stalk. Pleurotus ostreatus degrade lignin significantly compared to hemicellulose in oil palm frond but it degrade more cellulose and hemicellulose in cocoa pod husk. Ganoderma lucidum is a good candidate for pretreating oil palm empty bunch since it can degrade lignin significantly and very less degrade polysaccharides. When evaluating the effectiveness of bioconversion process, it is critical to evaluate the ratio of the amount of lignin degraded per total cellulose and hemicellulose loss. For the purpose of animal feed production, the upgrading effects of biological pretreatment on LCB should be expressed by its strong degradation of lignin or breaking the linkages between the lignin and the polysaccharides with minimum degradation of the polysaccharides (cellulose and hemicellulose). The cellulose or hemicellulose should be conserved during the biological processing to fully utilized by ruminant through microbial fermentation in the rumen.

The composition of the constituents that build the lignin and its structure have been reported to be important factor that affect on its degradability by biological processing treatment (Van Kuijk et al. 2015). The time of incubation required to obtain maximum loss of lignin is also important since it may affect the palatability and voluntary intake of substrates when fed to ruminant animals. Mustabi et al. (2018) studied the fermentation of cocoa pod using several isolates of white rot fungi and concluded that Lentinus torulosus had the highest lignolytic activity and less cellulolytic and hemicellulolytic activities compared to Coprinus comatus and Corilopsis polyzona. 
Table 3. Effects of biological-based process on the main polymer components of several LCBs potentially used as feed for ruminant

\begin{tabular}{|c|c|c|c|c|c|}
\hline \multirow{3}{*}{$\begin{array}{l}\text { Fungi } \\
\text { Phanerochaete crysosphorium }^{1)}\end{array}$} & \multirow{3}{*}{$\begin{array}{r}\text { Substrate } \\
\text { PPF }\end{array}$} & \multicolumn{2}{|c|}{ Component of LCB Degraded/Loss (\%) } & \multirow{2}{*}{\multicolumn{2}{|c|}{$\begin{array}{c}\text { Incubation (days) } \\
\text { Hemi cellulose }\end{array}$}} \\
\hline & & \multirow{2}{*}{$\begin{array}{c}\text { Lignin } \\
22.8\end{array}$} & \multirow{2}{*}{$\frac{\text { Cellulose }}{15.1}$} & & \\
\hline & & & & - & 7 \\
\hline Phanerochaete crysosphorium ${ }^{2}$ & Maize stalk & 6.8 & 9.4 & 14.1 & 10 \\
\hline Phanerochaete chrysosporium ${ }^{3)}$ & Wheat straw & 47.6 & 59.2 & 67.2 & 30 \\
\hline Phlebia floridensis ${ }^{3)}$ & Rice straw & 6.2 & 4.7 & 5.8 & 20 \\
\hline Phlebia floridensis ${ }^{3)}$ & Rice straw & 39.4 & 52.0 & 50.9 & 60 \\
\hline Phlebia floridensis ${ }^{4)}$ & Wheat straw & 30.6 & - & - & 30 \\
\hline Phlebia brevispora ${ }^{3)}$ & Rice straw & 20.0 & 12.8 & 8.7 & 60 \\
\hline Phlebia fascicularia ${ }^{3)}$ & Rice straw & 19.6 & 10.3 & 21.0 & 60 \\
\hline Pleurotus ostreatus $^{5)}$ & OPF & 7.24 & - & 1.39 & 90 \\
\hline Pleurotus pulmonarius ${ }^{6)}$ & Sorghum stalk & 31.9 & - & 5.8 & 30 \\
\hline Ganoderma lucidum ${ }^{7)}$ & OPEFB & 31.5 & 2.1 & 14.1 & 48 \\
\hline Lentinus torulosus ${ }^{8)}$ & Cocoa pod & $1.4-12.3$ & - & - & $15-30$ \\
\hline Crinipellis sp. ${ }^{9)}$ & Wheat straw & 12.6 & 10.3 & 28.9 & 10 \\
\hline
\end{tabular}

${ }^{1)}$ Fariani et al. 2015; ${ }^{2}$ Tao et al. 2016; ${ }^{3)}$ Sharma \& Arora 2014; ${ }^{4)}$ Arora et al. 2011; ${ }^{5}$ Metri et al. 2018; ${ }^{6}$ Jonathan et al. 2012; ${ }^{7)}$ Nazratul et al. 2019; ${ }^{8}$ Mustabi et al. 2018; ${ }^{9}$ Shrivastava et al. 2014; PPF: Palm press fiber; OPF: Oil palm fronds; OPEFB: Oil palm empty fruit bunch.

When evaluating the biological process of LCB for animal feed production it is important to consider the potential effect of this processing on the dry matter loss during the process which can range from 11 to $42 \%$ (Mahesh \& Mohini 2013). The rate of DM loss during the process is associated with the incubation periode and the maximum incubation period of 6-8 days for animal feed production has been recommended (Owen et al. 2012).

\section{RESPONSE OF RUMINANTS TO BIOLOGICAL BASED PROCESSED LCBS}

Studies in goats (Chanjula et al. 2018) showed a slight increase $(5.5 \%)$ in DM intake and digestibility when oil palm frond pretreated with Lentinussajor-caju was included at $30 \%$ of diet (DM). Inclusion of rice straw pretreated with Pleurotus ostreatus in diet of lactating goats to replace Trifolium alexandrinum as forage by 25 or $45 \%$ resulted in no effect on feed intake, DM digestibility, but milk fat content were higher in rice straw diet (Kholif et al. 2014). Other study showed no effects on feed intake, milk production and ruminal fermentation in dairy cows fed sugar cane bagasse pretreated with Pleutorus sajorсаju (Sirisan et al. 2019). Increase rate of digestion of cellulose and hemicellulose by almost $100 \%$ was found in sheep fed diet containing $17 \%$ maize stalk pretreated with Phanerochaete chrysosporium in a total mixed ration (Tao et al. 2016). These studies indicate that increase in DM or OM digestibilities are the most common effects of biologically pretreated LCBs and this is related to the increase the bioavailability of cellulose and hemicellulose. Further increase in feed efficiency of utilization would be expected. As reviewed by Van Kuijk et al. (2015) most studies in biologically processing treatment have focused on single substrate inoculated with single fungal species and suggested that co-cultures of fungal species might provide better results as compared to monoculture. Tao et al. (2016) used co-cultured Phanerochaete chrysosporium and Aspergillus niger or Phanerochaete chrysosporium and Trichoderma viride and found increase loss of lignin after incubation for 10 days, but unfortunately increased loss of cellulose and hemicellulose was also found. Nayan et al. (2018) recently screen a number of white rot fungi species and found that Ceriporiopsis subvermispora strains show an overall high potential to improve the in vitro ruminal degradability of wheat straw, followed by Lentinula edodes and Pleutrotus eryngii strains. 


\section{PROSPECTS OF LCB PROCESSING TECHNOLOGIES IN INDONESIA RUMINANT PRODUCTION SYSTEM}

Ruminant production system in Indonesia is typically traditional farming system operated under integrated crop-livestock system. The dominant crops involve in this mixed system are cereal crops such as rice and maize and legume crops. LCB in the form of straw, stalk, stover are produced from this system. In drier part of Indonesia or during long dry season these crop residues are becoming more important as fodder for ruminants. Currently, there is considerable attention and effort to expand the ruminant production through integration with plantation crop such as oil palm, cacao and sugar cane where huge amount of biomass are produced (Table 4). Combining these biomasses with those from food crop residues produced by smallholder farms generate great amount of LCB that could be used to feed ruminant animals in Indonesia. However, most of the LCB from the oil palm industry are lack of energy contain to support the production of ruminants (Ginting et al. 2018). Studies of Puastuti et al. (2010) in sheep and of Puastuti \& Yulistiani (2011) in goats indicated that pretreated cocoa pod in diets increase ADG. The potential application of processing techcnologies to support ruminant production indicated by the fact that differences of crop residue nutritive quality as low as 3 to $5 \%$ unit in organic matter digestibility can have a significant effect on livestock productivity (Blümmel et al. 2013). Thus, there is potential for applying selective processing technologies that fit to the existing ruminant production setting for upgrading feed resources from LCB.

The improvement of LCB nutritive quality through processing technologies would influence the trade-off of crop residue uses (feed, mulching for soil fertility) that are common in the mixed crop-livestock system (Valbuena et al. 2015). Assessing the specific properties of those processing technologies to indicate their potential and constraints would be a worthy tool to make recommendation of their prospective application in specific ruminant production system. The properties of the processing technologies are assessed from technical, economical or environmental perspectives. Advantages properties of the processing technologies such as delignification capacity, minimum degradation of cellulose and hemicellulose, avoiding of negative effect on the palatability, avoiding of toxic compound generation, cost effectivity, technical simplicity and environmental friendly are the properties related to the animal feed production.

Physical process such as chopping and shredding are relatively simple and less expensive and so should be suited for small scale and industrial ruminant production. Except for production of pellet feed, ballmilled process is extremely expensive due to high energy consumption. Nutritionally, there is limitation due to fine particles produced that can escape more easily from the rumen before being digested (Falls et al. 2017). Most chemical processings are relatively costly, less safe and potentially cause environmental pollution. AFEX are preferred since they removed most the lignin (Rizal et al. 2018). AFEX technologies is effective on straw, stover and stalk of cereal crops and sugar cane (Balan 2014). The AFEX processing also produces only solid product that make it a prospective option (Blümmel et al. 2014). The aqueous ammonia soaking (AAS) could be a prospective treatment for oil palm processing residues such as oil palm empty bunch and oil palm mesocarp that contain high level of lignin. The urea processing is seemed to be the most adaptive processing technology for the mix crop- livestock smallholders. It is cheaper compared to other alkaline treatment, and it is easily applied at either farm or industrial levels with no potential for environmental pollution. Ammonia and urea treatments have technical advantages (easy to perform and safe), economic advantages (less costly) and nutritional advantages (extra crude protein). The common method used is using $4 \mathrm{~kg}$ of urea per $100 \mathrm{~kg}$ straw soaked in 60-100 L of water for 1-2 weeks (Schiere 2010). Processing treatment using hydrogen peroxide could be prospective in industrial ruminant production since it operates in mild condition and does not pollute the biomass (Kucharska et al. 2018). Biological treatment using solid state fermentation method require much less energy and infrastructures to operate, and environmentally safe and could be a potentially prospective processing technology for small scale and industrial ruminant production.

Table 4. The potential of biomass from plantation crops in main regions of Indonesia

\begin{tabular}{lll}
\hline \hline Region & Biomass production, t DM/year & Main crops \\
\hline Sumatera & $274,633,807$ & Oil palm, cacao, sugar cane \\
Kalimantan & $22,726,190$ & Oil palm, cacao \\
Sulawesi & $3,602,733$ & Cacao \\
Java & $2,067,509$ & Sugar cane \\
\hline
\end{tabular}

Source: Calculated from Widiawati et al. (2019) 
However, Kuijk et al. (2015) suggested that biological processing treatment would have greater potential application at industrial scale when there are fungal strain that have been selected with improved genetic potential for use under optimal cultivation and harvesting conditions. Although productivity of ruminant animals could be improved significantly by processing technologies on LCB, the large adoption of processing technologies in the Indonesia production system are rare. This may associate with the typical smallholder ruminant production system where little direct benefit would be expected from higher animal productivity through technology uptake. However, the increasing demand of meat for growing population will encourage a more intensive ruminant production system either under integrated crop-animal production or the feedlot industry systems. As production system become more intensive and less land is available for forage production the processing technologies to optimaize the use of LCB as feed for ruminants is becoming more prospective.

\section{CONCLUSION}

There are many recent and novel processing technologies that have been developed to process LCB originally designed for the purpose of biofuel production. Principally, these technologies are compatible for production of LCB-based ruminant feeds. Ruminant animals have responded positively to the pretreated LCB when included in diet at various levels as indicated by the increased DM and OM digestibility of diet and better rate of gain or milk production. Selection for the appropriate technologies for animal feed production need to consider the economic, technical and environmental aspects. Currently, acids treatment seem to be the least prospective for animal feed production at present due to the economic and environment point of view. In ruminant production system, among the alkaline basedprocessings, the urea treatment still remains the most prospective chemical processing technology for smallholders, while for intensive and industrial ruminant production system the AFEX processing technologies is considered to be prospective.

\section{REFERENCES}

Adesogan AT, Arriola KG, Jiang Y, Oyebade A, Paula EM, Pech-Cervantes AA, Romero JJ, Ferraretto LF, Vyas D. 2019. Symposium review: Technologies for improving fiber utilization. J Dairy Sci. 102:57265755.

Aditya HB, Mahlia TMI, Chong WT, Nur H, Sebayang. AH. 2016. Second generation biothermal production: A critical review. Renew Sustain Energy Rev. 66:631653.

Agbor VB, Cicek N, Sparling R, Berlin A, Levin DB. 2011. Biomass pretreatment: Fundamentals toward application. Biotechnol Adv. 2:675-685.

Ahmadi F, Zamiri MJ, Khorvash M, Ziaee E, Polikarpov I. 2016. Pre-treatment of sugarcane bagasse with a combination of sodium hydroxide and lime for improving the ruminal degradability: optimization of process parameters using response surface methodology. J Appl Anim Res. 44:287-296.

Akram MZ, Firincioglu SY. 2019. The use of agricultural crop residues as alternatives to conventional feedstuffs for ruminants: A Review. Eurasian J Agric Res. 3:58-66.

Alexandratos N, Bruinsma J. 2012. Wold agriculture toward 2030/2050 the revision 2012. Food Agricultural Organization United Nations. 146. doi: 10.1016/S0264.8377(03)00047-4.

Arora DS, Sharma RK, Chandra P. 2011. Biodelignification of wheat straw and its effect on in vitro digestibility and antioxidant properties. Int Biodeteriotation Biodegradation. 65:352-358.

Balan V. 2014. Current challenges in commercially producing biofuel from lignocellulosic biomass. ISRN Biotechnology. Article ID 463074. doi: $10.1155 / 2014 / 463074$

Barlianti V, Hendarsyah DH, Abimanyu.H. 2015. Effects of alkaline pretreatments on properties of lignocellulosic oil palm waste. Proced Chem. 16:195-201.

Behera S, Dahnum, Arora R, Nandhagopal N, Kumar S. 2014. Important of chemical for bioconversion of lignocellulosic bimass. Renew Sustain Energy Rev. 36:1-106.

Bhat SM, Shilpa. 2015. Lignocellulosic feestock conversion, inhibitor detoxification and cellulosic hydrolysis-a review. Biofuels. doi: 10.1080/17597269.2014. 1003702 .

Blümmel M, Homann-Kee TS, Valbuena D, Duncan AJ, Herrero M. 2013. Biomass in crop livestock system in the context of the livestock revolution. Secheresse. 24:330-339. doi: 10.1684/sec.2013.0403.

Blümmel M, Steele B, Dale BE. 2014. Opportunities from second generation biofuel technologies for upgrading lignocellulosic biomass for livestock feed. CAB Reviews. Vol. 9 No. 041.

[BPS] Badan Pusat Statistik. 2020. Luas panen dan produksi padi di Indonesia 2019. Jakarta (Indonesia): Badan Pusat Statistik. $333 \mathrm{hlm}$

Casperson BA, Wertz-Lutz AE, Dunn JL, Donkin SS. 2018. Inclusion of calcium hydroxide- treated corn stover as a partial forage replacement in diets for lactating dairy cows. J Dairy Sci. 101:2027-2036.

Chanjula P, Petcharat V, Cherdthong A. 2018. Rumen characteristics and feed utilization in goats fed with 
biologically treated oil palm fronds as roughage in a total mixed ration. South Afr J Anim Sci. 48:10491056.

De Moraes Rocha GJ, Nascimento VM, Goncalves AR, Silva VFN, Martin C. 2015. Influence of mixed sugarcane bagasse samples evaluated by elemental and physical chemical composition. Ind Crops Prod. 64:52-58.

Fariani A, Abrar A, Muslim G, Warly L. 2015. Suplementation of fermented palm press fibre on digestibility of rice straw and rumen bacteria profile. Pak J Nutr. 14:80-83.

Falls M, Meysing D, Liang C, Karim MN, Carstens G, Tedeschi LO, Holtzapple MT. 2017. Development of highly digestible animal feed from lignocellulosic biomass Part 2: Oxidative lime pretreatment (OLP) and shock treatment of corn stover. Transl Anim Sci. $1: 215-220$

Financiea R, Moniruzzamana M, Uemuraa Y. 2016. Enhanced enzymatic delignification of oil palm biomass with ionic liquid pretreatment. Biochem Engineering J. 110:1-7.

Ginting SP, Simanihuruk K, Tarigan A, Pond KR. 2018. Nutritional support for small ruminant development based on oil palm by-products. Wartazoa. 28:189198

Guerriero G, Hausman J-F, Strauss J, Ertan H, Siddiqui KS. 2016. Lignocellulosic biomass: Biosynthesis, degradation and industrial utilization. Eng Life Sci. 16:1-16.

Guilherme AA, Dantas PVF, Soares JCJ, dos Santos ES, Fernandes FAN, de Macedo GR. 2017. Pretreatment and enzyme hydrolysis of sugar cane bagasse aiming at the enhancement of the yield of glucose and xylose. Braz J Chem Eng. 34:934-947.

Hashim R, Nadhari WNAW, Sulaiman O, Kawamura F, Hiziroglu, Sato SM, Sugimoto T, Seng TG, Tanaka R. 2011. Characterization of raw materials and manufactured binderless particle board from oil palm biomass. Materials Design. 32:246-254.

Hassim HA, Lourenco M, Goh YM, Baars JJP, Flevez V. 2012. Rumen degradation of oil palm fronds is improved through pre-digestion with white rot fungi but not through supplementation with yeast or enzymes. Can J Anim Sci. 92:79-87.

Huang YF, Chiueh PT, Lo SL. 2016. A review on microwave pyrolysis of lignocellulosic biomass. Sustain Environ Res. 26:103-109.

Ichwan M, Son TW. 2011. Study on organosolv pulping methods of oil palm biomass. In: International Seminar on Chemistry. p. 364-370

Intasit R, Yeesang J, Cheirsilp B. 2019. Biological pretreatment of empty fruit bunch (EFB) using oleaginous Aspergillus tubingensis TSIP9. J Water Environ Technol. 17:244-250.
Jonathan SG, Okorie AN, Garuba EO, Babayemi OJ. 2012. Bioconversion of sorghum stalk and rice straw into value added ruminant feed using Pleurotus pulmonarius. Nat Sci. 10:10-16.

Karunanithy V, Muthukumarappan K. 2011. Optimizing extrusion pretreatment and big blustem parameters for enzymatic hydrolysis to produce biofuel using response surface methodology. Int J Agric Biol Eng. 4:61-74.

Kholif AE, Khattab HM, El-Shewy AA, Salem AZM, Kholif AM, El-Sayed MM, Gado HM, Mariezcurrena MD. 2014. Nutrient digestibility, ruminal fermentation activities, serum parameters and milk production and composition of lactating goats fed diets containing rice straw treated with Pleurotus ostreatus. Asian Australas J Anim Sci. 3:357-364.

Kristiani A, Abimanyu H, Setiawan AH, Sudiyarmanto, Aulia F. 2013. Effect of pretreatment process by using diluted acid to characteristic of oil palm's frond. Energy Procedia. 32:183-189.

Kucharska K, Rybarczyk P, Holowacz I, Lukajtis R, Glinka M, Kaminski M. 2018. Pretreatment of lignocellulosic materials as substrate for fermentation processes. Molecules. 23:2937-2968.

Kumar AK, Sharma S. 2017. Recent updates on different methods of pretreatment of lignocellulosic feedstocks: A review. Bioresour Bioprocess. 4:7-26.

Laconi EB, Jayanegara A. 2015. Improving nutritional quality of cocoa pod (Theobroma cacao) through chemical and biological treatments for ruminant feeding: in vitro and in vivo evaluation. Asian Australas J Anim Sci. 28:343-350.

Latif AB, Harun S, Sajab MS, Markom M, Jahim JM. 2018. Ammonia-based pretreatment for lignocellulosic biomass conversion-An overview. J Eng Sci Technol. 13:1595-1620.

Lee J, Jeffries TW. 2011. Efficiencies of acid catalysts in the hydrolysis of lignocellulosic biomass over a range of combined severity factors. Biosour Technol. 102:5884-5890.

Lee JC, Houtman J, Kim H, Choi I, Jeffries TW. 2011. Scaleup study of oxalic acid pretreatment $\mathrm{g}$ of agricultural lignocellulosic biomass for the production of bioethanol. Biores Technol. 102:7451-7456.

Lini FZ, Widjaja T, Hendrianie N, Altway A, Nurkhamidah S, Tansil Y. 2018. The effect of organosolv pretreatment on optimization of hydrolysis process to produce the reducing sugar. MATEC Web of Conferences 154, 01022. The 2nd International Conference on Engineering and Technology for Sustainable Development. 7 p.

Lucas M, Hanson SK, Wagner GL, Kimball DB, Rector KD. 2012. Evidence for room temperature delignification of wood using hydrogen peroxide and manganese acetate as catalyst. Bioresour Technol. 11:174-180. 
Mafa MS, Malgas S, Bhattacharya A, Rashamuse K, Pletschke BI. 2020. The effects of alkaline pretreatment on agricultural biomass (corncob and sweet sorghum bagasse) and their hydrolysis by a termite-derived enzyme cocktail. Agronomy. 10:1211. doi: 10.3390/agronomy10081211.

Mahesh MS, Mohini M. 2013. Biological treatment of crop residues for ruminant feeding: A review. Afr J Biotechnol. 12:4221-4231.

Makarim AK, Sumarno, Suyamto. 2007. Jerami padi: pengelolaan dan pemanfaatan. Bogor (Indonesia): Pusat Penelitian dan Pengembangan Tanaman Pangan. Badan Litbang Pertanian, Kementerian Pertanian. $52 \mathrm{p}$.

Malik K, Tokkas J, Anand RC, Kumari. 2015. Pretreated rice straw as an improved fodder for ruminants-An overview. J Appl Nat Sci. 7:514-520.

Maryana R, Ma'rifatun D, Wheni A, Satriyo KW, Rizal WA. 2014. Alkaline pretreatment on sugarcane bagasse for bioethanol production. Energy Procedia 47:250-254.

Metri Y, Warly L, Suyitman. 2018. Biodegradation of lignin by white rot fungi (Pleurotus ostreatus) to decrease the fibre components in the palm midrib. Pak J Nut. 17:71-75.

Mor P, Bals B, AK Tyagi, Tyagi FN, Kumar S, Bringi V, Vande Haar M. 2018. Effect of ammonia fiber expansion on the available energy content of wheat straw fed to lactating cattle and buffalo in India. J Dairy Sci. 101:7990-8003

Mor P, Bals B, Kumar S, Tyagi N, Reen JK, Tyagi B, Choudhury PK, Tyagi AK. 2019. Influence of replacing concentrate mixture with AFEX pellets on rumen fermentation, blood metabolites and acetamide content in the rumen of crossbred (Alpine $\mathrm{x}$ Beetle) female goats. Small Rumin Res. 170:109-115.

Mottet A, de Haan C, Falcucci A, Tempio G, Opio C, Gerber P. 2017. Livestock: On our plates or eating at our table? A new analysis of the feed/food debate. Global Food Security. doi: 10.1016/j.gfs.2017.01.001.

Muscat A, de Olde EM, de Boer IJM, Ripoll-Bosc R. 2019. The battle for biomass: A systematic review of foodfeed-fuel competition. Global Food Security. doi: 10.1016/j.gfs.2019.10033

Mustabi J, Wedawati, Armayanti AK. 2018. Improving quality and digestibility of cocoa pod with white rot fungi. IOP Conf Series: Earth and Environmental Science 157. doi:10.1088/1755-1315/157/1/012002.

Mokomele T, da Costa Sousa L, Bals B, Balan V, Goosen N, Dale BE, Grogens JF.2018. Using steam explosion or AFEX to produce animal feed in a biorefinery based on sugarcane residues. Biofuel Bioproduct Biorefining. 12:978-996.

Montgomery LFR, Bochmann G. 2014. pretreatment of feedstock for enhanced biogas production. Baxter D, editor. IEA Bioenergy. 24 p.
Nayan N, Sonnenberg ASM, Hendriks WH, Cone JW. 2018. Screening of white-rot fungi for bioprocessing of wheat straw into ruminant feed. J Appl Microbiol. doi: 10.1111/jam.13894.

Nazir N, Novelina, E. Juita, C. Amelia, Fatli R. 2016. Optimization of pre-treatment process of cocoa pod husk using various chemical solvents. Int J Adv Sci Eng Information Technol. 6:403-409.

Nazratul N, Rakib FMY, Zailan MRM, Yaakub H. 2019. Nutritive composition of oil palm empty fruit bunch fibers treated with mycelia culture of Lingzhi (Ganoderma lucidum) as a potential ruminant feedstuff. Mal J Anim Sci. 22:35-46.

Nitsos R, Rova U. 2017. Organosolv fractionation of softwood biomass for biofuel and biorefinary application. Energies. 11:50.

Owen H, Smith T, Makkar HPS. 2012. Succes and failure with animal nutrition practices and technologies in developing countries. A synthesis of an FAO econference. Anim Feed Sci Technol. 174:211-226.

Panahi HKS, Dehhaghi M, Aghbashlo M, Karimi K, Tabatabaei M. 2020. Conversion of residues from agro-food industry into bioethanol in Iran: An undervalued biofuel additive to phase out MTBE in gasoline. Renewable Energy. 145:699-710.

Puastuti W, Yulistiani D, Mathius IW, Giyai F, Dihansih E. 2010. Ransum berbasis kulit buah kakao yang disuplementasi $\mathrm{Zn}$ organik: respon pertumbuhan pada domba. JITV. 16:269-277.

Puastuti W, Yulistiani D. 2011. Utilization of urea and fish meal in cocoa pod silage based rations to increase the growth of Etawah crossbred goats. In: Ali A, Kamil KA, Alimon AR, Orskov, Zentek J, Tanuwiria UH, editors. Proceeding 2nd International Seminar AINI Feed Safety Health Food. Bandung, July 6-7th, 2011. Bandung (Indonesia): Padjadjaran University. p. 463469.

Rizal NA, Ibrahim MF, Zakaria M, Bahrin EK, Abd Aziz S, Hassan M. 2018. Combination of superheated steam with laccase pretreatment together with size reduction to enhance enxymatic hydrolysis of oil palm biomass. Molecule. 23:811-817.

Rusli ND, Azmi MA, Mat K, Hasnita CH, Wan-Zahari M, Azhar M, Zamri-Saad K, Hassim HA. 2019. The effect of physical and biological pre-treatments of oil palm frondson in vitro ruminal degradability. Pertanika J Trop Agric Sci. 42:791-805.

Saha BC, Cotta MA. 2014. Alkaline peroxide pretreatment of corn stover for enzymatic saccharification and ethanol production. Industrial Biotechnol. 10:34-41.

Schiere JB. 2010. Cereal straw as ruminant feeds: Problem and prospects revisited. Anim Nutr Feed Technol. 10S:127-153.

Sharma RK, Arora DS. 2014. Bioprocessing of wheat and paddy straw for their nutritional up-grading. Bioprocess Biosyst Eng. 37:1437-1445. 
Shreck AL, Nuttelman BL, Harding JL, Griffin WA, Erickson GE., Klopfenstein TJ, Cecava MJ. 2015. Digestibility and performance of steers fed lowquality cropresidues treated with calcium oxide to partially replace corn in distillers grains finishing diets. J Anim Sci. 93:661-671.

Sirisan V, Pattarajinda V, Duanyai S. 2019. Effect of feeding sugarcane bagasse treated with alkali and white rot fungi on dairy cow performance, blood metabolite and ruminant fermentation. Indian $\mathrm{J}$ Anim Res. doi: 10.18805/ijar.B-1084.

Swain MR, Krishnan C. 2015. Improved conversion of rice straw to ethanol and xylitol by combination of moderate temperature ammonia pretreatment and and sequencing fermentation using Candida tropicalis. Industr Crops Prod. 77:1039-1046.

Talaiekhozani A, Rezania S. 2020. A critical review on the various pretreatment technologies of lignocellulosic materials. J Env Treatment Tech. 8:925-935.

Tan,H.T, Lee KT, Mohamed AR. 2011. pretreatment of lignocellulosic palm biomass using a solvent-ionic liquid [BMIM] $\mathrm{Cl}$ for glucose recovery: An optimization study using respons surface methodology. Carbohydr Polym. 83:1862-1868.

Tao L, Zhang LX, Tu Y, Zhang NF, Si BW, Ma T, Diao QY. 2016. Improving thr in situ ruminal degradability of maize stalk using inoculant in dorper $\mathrm{x}$ thin-tailebhan crossed ewes. Small Rumin Res. 144:119-125.

Uppugundla N, da Costa Sousa L, Chundawat SPS, Yu, Simmons XB, Singh S, Gao X, Kumar R, Wyman C.E, Dale BE, Balan V. 2014. A comparative study of ethanol production using dilute acid, ionic liquid and AFEX ${ }^{\mathrm{TM}}$ pretreated corn stover. Biotechnol Biofuels. 7:72-85.

Valbuena D, Sabine HT, Erenstein O, Teufel N, Duncan A, Abdoulaye T, Swain B, Kekonnen K, Germaine I, Gérard B. 2015. Identifying determinants, pressure and trade-off of crop residue use in mixed smallholder farms in Sub-Saharan Africa and South Asia. Q Agric Syst. 134:107-118.

Van Kuijk SJA, Sonnenberg ASM, Baars JJP, Hendricks WH, Cone JW.2015. Fungal treated lignocellulosic biomass as ruminant feed ingredient: A Review. Biotechnol Adv. 33:191-202.

Van Zanten HHE, van Ittersum MK, De Boer IJM. 2019. The role of farm animals in a circular food system. Global Food Security. 21:18-22.

Wang K, Nan X, Tong J, Zha G, Jiang L, Xiong B. 2020. Steam explosion pretreatment changes ruminal fermentation in vitro of corn stover by shifting archaeal and bacterial community structure. Front Microbiol. 11:1-10.

Wang Y, McAllister TA, Lora JH. 2017. Effect of purified lignin on in vitro rumen metabolism and growth performance of fee lot cattle. Asian-Austral J Anim Sci. 30:392-399.

Widiawati Y, Matondang RH, Rahayu CT, Hidayat IR, Ramadhan BA, Fauzi MI. 2019. Bahan pakan ruminansia berbasis produk samping/biomassa industri perkebunan. Bogor (Indonesia): IPB Press. $226 \mathrm{p}$.

Wu H, Zhou Z, Yang Y, Meng Q. 2020. Effect of steam explosion of oil palm frond and empty fruit bunch on nutrient composition and ruminal fermentation characteristics. Trop Anim Health Prod. 52:12231228 .

Yulistiani D, Puastuti W. 2012. Produk samping pertanian untuk pakan dan prediksi emisi gas metana pada ruminansia. Dalam: Potensi bahan pakan lokal untuk menurunkan gas metana ternak ruminansia. Jakarta (Indonesia): IAARD Press.

Zakaria MR, Hirata S, Hassan MA. 2014. Combine pretreatment using alkaline hydrothermal and ball milling to enhance enzymatic hydrolysis of oil palm mesocarpfibre. Bioresour Technol. 169:236-243. 